\title{
Teachers' Educational Needs and Their Motives for Participation in Lifelong Learning in Greece
}

\author{
Konstantina Kiriatzakou \\ University of Macedonia, Thessaloniki \\ School of Social Sciences, Humanities and Arts
}

Received 28 October 2018 - Revised 25 December 2018 - Accepted 28 December 2018

\begin{abstract}
The aim of the study is to investigate teacher's educational needs in terms of their teaching work and scientific profile and to examine the frequency and motives of their participation in training programs. The survey focuses on Primary and Secondary Education teachers of all fields across the Greek territory. The majority of the 556 who completed the questionnaire have attended training programs-workshops during the previous two years (95.4\%). Regarding the participation in training programs with specific thematic areas over the past two years, higher participation rates are observed in new teaching methods (32.9\%) and New Technologies (ICT) (31.1\%) with the areas of Teaching Methodology (27.6\%) and Addressing Learning Difficulties (27\%) following. Low participation rates are observed in the training programs on stress management strategies $(7.5 \%)$ and the topics related to the evaluation of the teaching process (9.8\%) and that of students' evaluation (10.7\%). Teachers also want to take part in training courses related to pedagogical and psychological issues and much less to courses related to the administration of education. Finally, teachers participate in training courses for their professional and personal development and much less for career development and personal pleasure (i.e. to meet people etc.).
\end{abstract}

Keywords: educational needs, teachers' participation, motives in training.

\section{Introduction}

The importance of this thesis is reflected in the European Union's increasing importance in professional development, teacher education and training, professional satisfaction and increased incentives to attract highly qualified teachers. World economic conditions make the profession of the teacher an important factor that plays a key role in the development of the economy by producing effective educational work and improving the quality of education.

The quality of education is a major priority issue for European and international education systems. Its definition and, furthermore, its evaluation is an extremely complex issue, influenced by political, economic, historical and social circumstances.

The introduction of "quality" in education comes from the economy and business areas, based on a concept that emphasizes organizational planning, risk management, certification and outflows and it is directly linked to the introduction and the use of "tech-management" terms (competitiveness, productivity, efficiency, accountability) in the public service sector (Morley \& Rassool, 2000; Borraz, 2007).

(C) Authors. Terms and conditions of Creative Commons Attribution 4.0 International (CC BY 4.0) apply. Correspondence: Konstantina Kiriatzakou, $\mathrm{PhD}$ candidate, $1^{\text {st }}$ Vosporou Street, 55132, KalamariaThessaloniki, GREECE. E-mail: kyriatzakou@uom.edu.gr. 
In the international literature there is no acceptable definition of the concept of quality, which is considered to be a "chameleon term" (Vidovich, 2001) and becomes important due to the reference framework (Harvey \& Green, 1993). Since the 1990s, a holistic approach to the concept has been attempted, including conditions such as the definition and achievement of excellence standards, the excellent fit-for-purpose relationship, the value for money, the quality assurance, the quality assessment, the quality improvement, the quality management, the quality of training and total quality control (Van Damme, 2000; Knight \& Trowler, 2000; Ursin, 2007; Harvey \& Stensaker, 2008).

- $\quad 95.4 \%$ of teachers have attended training programs during the previous two years.

- Higher participation rates are observed in new teaching methods and ICT.

- Teachers request courses related to pedagogical and psychological issues.

- Teachers participate in training for their professional and personal development.

Since the early 1980s, a demand for "high quality education for all" has been raised. Thus, in the 1980 s and 1990 one of the main issues for teacher education globally, concerned its upgrading in order to be carried out by higher education institutions. In the first decades of the $\mathbf{2 1}^{\text {st }}$ century, the main issues are the further increase of teachers' level in order to entrance in the educational profession, and the retreat of the existing model of teacher education by incorporating initial training into a vocational/learning continuum, starting from selection procedures for candidate teachers, including their basic studies and the period of their initiation into the educational profession and continuing with their professional development (OECD, 2005; Buchberger et al., 2000).

The common European principles on the abilities and qualifications of teachers describe the profession of European teacher with the following characteristics:

- It is a highly qualified profession. All teachers are graduates of higher education institutions (and those working in the field of initial vocational training have high qualifications in their professional sector and appropriate pedagogical skills). Each teacher has extensive knowledge of each subject he/she teaches, good knowledge of pedagogy, the skills and abilities required to guide and support learners, and an understanding of the social and cultural dimension of education (Eurydice, 2004: 12-18).

- It is a life-long learning profession. Teachers are encouraged to continue their professional development throughout their careers. Both they and their employers recognize the importance of acquiring new knowledge, innovating and introducing new elements into their work.

- It is a profession characterized by mobility. Mobility is a central component of initial and continuing teacher education programs. Teachers are encouraged to work or study in other European countries for professional development purposes.

- It is a profession based on partnership. Teacher training institutions organize their work in partnerships with schools, local work environments, job-based training providers and other stakeholders. The European Commission's texts show that teachers should work and collaborate with others in order to be able to meet the new requirements of their profession. They should also use technology and information, work with the society and within it, contributing to the assurance of the quality of their work.

\section{Training for professional development and improving the quality of education}

In the international literature, three main dimensions of training are distinguished. Firstly, emphasis is given to its compensatory character as a complement to the inadequate initial or basic educational training of teachers. Secondly, training is considered as a modernization of 
the cognitive stock of active teachers. Finally, training is related to the personal and professional development of the teacher and accompanies him/her throughout his/her service in education (Xohellis, 2005: 111). In addition, the European citizen should have access to education and training throughout his life, gradually aiming at the creation of a learning society (Sipitanou, 2005: 95).

The term "teachers' professional development" does not always appear with the same conceptual range in the literature. Keiny (1994: 157-167), studying the professional development of teachers in the light of social constructivism, considers that professional development is limited to investigating teachers' professional experiences and using them as input in order to construct and develop new teaching theories. Hargreaves and Fullan (1995) approach the development of teachers through the development of knowledge and skills, their self-awareness and adaptation to the social and educational environment, the improvement of their teaching capacity, the development of teachers' cooperation with each other and the deeper awareness of their role in society. Day (2003: 25-26) identifies four learning environments: (a) direct teaching (through conferences, courses, experiential and counseling meetings); (b) learning at school (e.g. through coaching, criticism from friends, evaluation, research practice, working with colleagues, etc.); (c) learning outside school (e.g. through reform networks, school or university partnerships, professional development centers, etc.), and (d) learning within the classroom (e.g. by responding to pupils).

The basic elements that define teachers' profession and the central characteristics of their professional development are the basic education, the autonomy in the exercise of the educational work, the continuous updating and training, the social mission of the teacher. Teachers, from an early age and for many years, follow an "informal apprenticeship" in the profession. However, learning only from experience limits their personal development (Day, 2003: 24). In fact, professional development is a continuous process of learning in which teachers acquire their professional knowledge and skills, as well as personal qualities and beliefs that enable them to fulfill their professional role (Papanaoum, 2014: 15).

The need to ensure high quality teaching is now one of the key objectives of the Strategic Framework for Education and Training (ET 2020). The framework highlights the importance of providing adequate initial education and continuing professional development for teachers as well as the need to make teaching an attractive career choice. An institution of strategic importance, both for the EU and for every national education system, and an integral part of a continuous and lasting professional and personal development of teachers is training. In Greece, training is provided on the one hand by specialized educational institutions (Regional Training Centers and others) and, on the other hand, by a variety of public or private sector bodies as well as through programs funded by the European Union. At the same time, a systematic and coherent policy of appropriate training for the trainers themselves has not been promoted. The aging of teachers moves part of the interest of educational policy from the initial education of candidate teachers and the initial training to the practices of continuing professional development of the training activity. At the same time, there are resolutions and reports pointing out that the teaching profession must become an attractive profession and attract highly qualified people.

The prospective for teacher training in a globalized economy is important, as teachers are considered to be key levers in promoting change. All this, however, requires a lifelong trained teacher. So, for all the above reasons, this study is considered necessary as it tries to clarify the educational needs and motives of teachers-basic elements of planning training programs - for their training and their teaching work. 
3. The study

\subsection{The aim of the study}

The aim of the study was to investigate the educational needs of teachers in terms of their teaching work, their scientific profile and development and to examine the frequency and the motives of their participation in training programs.

The survey focused on Primary and Secondary Education teachers of all fields across the Greek territory. Thus, individuals who participated in the research are primary and secondary school teachers of: (a) general elementary and nursery schools, (b) model and experimental schools (kindergartens, elementary schools, high schools and lyceums), (c) second chance secondary schools, (d) general and technical secondary schools, and (e) special education schools.

\subsection{Methodology}

The method of stratified sampling was chosen for the best representation of the Greek teachers. This method of sampling was designed to ensure representation of all sections of the target population, in this case teachers, to reduce the estimation error and to have a sufficient number of subjects from subpopulations (Zafeiropoulos, 2015: 161). In particular, the type of proportional stratified sampling was chosen in order for the total sample to be a proportional miniature of the target population, since in each layer a sample is chosen so that the ratio of the sample size in the layer to the size of the total sample is equal to the ratio of the size of the population of the stratum to the size of the total population (Zafeiropoulos, 2015: 162).

2,255 schools were selected, a number that corresponds to $15.5 \%$ of all public primary and secondary schools. The choice of schools was initially made by region of education, then by administration of education and ending by municipality. At each stage of the selection, an attempt was made to select $15.5 \%$ of each type of school.

From the above selection of schools, special and experimental schools of primary and secondary education were excluded, as it was preferred to take the sum of the schools of these two categories into the selection of the school units to be sent the questionnaire. The reason for this was to have as much representation of the teachers of these types of schools in the sample of research as possible since the number of these schools is small nationwide.

\subsection{The questionnaire}

The first part of the questionnaire consists of questions concerning demographic factors such as gender, age, position of service (principal, vice principal, teacher), type of school and number of teachers serving in the school unit (Urban, suburban, rural), prefectural service and educational qualifications (titles, familiarity with computers, knowledge of foreign languages).

The second part of the questionnaire refers to lifelong learning and participation of teachers in training programs. In particular, the first question concerns the optional participation in seminars and training programs as well as the number of seminars-programs attended by the teachers of the sample during the previous school year, which are distinguished in seminars of 120 hours, 21-50 hours of seminars, 51-100 hours and 101 hours or more. The second question concerns the preferences of teachers regarding the forms of training: (a) training in Training Centers (RTC), (b) in-school training, (c) distance learning, (d) mixed training model, (e) participation in teacher education networks/communities, (f) mentoring, and (g) teachers' exchanges through European programs. The third question investigates the main thematic programs that teachers participated in. The fourth question investigates the educational needs of 
the participants concerning their educational work, professional development end promotion. Finally, the fifth question investigates their motives of participation to lifelong learning activities.

4. Demographic characteristics of the sample

562 primary and secondary school teachers participated in the survey conducted using a questionnaire. The number of recoverable final questionnaires amounted to 556. All the participants completed the questionnaire between December 2016 and April 2017. The statistical analysis of the data was carried out with the SPSS software programme for Windows Release 21 and Amos 22.

The sample is made up of $71.2 \%$ women and $28.8 \%$ men, reflecting the tendency for women to outnumber men in the Greek education system. A 19.8\% of the sample is aged between 41 and $45,27.7 \%$ from 46 to 50 and $20.7 \%$ of the sample are aged between 51 and 55 (Table 1).

Table1. Sample distribution by gender and age

\begin{tabular}{|l|c|c|}
\hline Gender & Frequency & Percentage \\
\hline Men & 160 & 28.8 \\
\hline Women & $\mathbf{3 9 6}$ & $\mathbf{7 1 . 2}$ \\
\hline Total & 556 & 100.0 \\
\hline Age & \multicolumn{2}{|c|}{} \\
\hline Up to 30 & 28 & 5.0 \\
\hline 31 to 35 & 48 & 8.6 \\
\hline 36 to 40 & 52 & 9.4 \\
\hline 41 to 45 & 110 & 19.8 \\
\hline $\mathbf{4 6}$ to 50 & $\mathbf{1 5 4}$ & $\mathbf{2 7 . 7}$ \\
\hline $\mathbf{5 1}$ to 55 & $\mathbf{1 1 5}$ & $\mathbf{2 0 . 7}$ \\
\hline 56 to 60 & 43 & 7.7 \\
\hline 60 and up & 6 & 1.1 \\
\hline Total & 556 & 100.0 \\
\hline
\end{tabular}

As we can observe in Table 1 the distribution of the sample by age shows that the participants are mainly middle-aged teachers who have years of experience in teaching. In table 2, we have the sample distribution by sector of service.

Table 2. Sample distribution by sector of service

\begin{tabular}{|l|c|c|}
\hline \multicolumn{2}{|c|}{ Frequency } & Percentage (\%) \\
\hline Sector of service & $\mathbf{3 2 4}$ & $\mathbf{5 8 , 3}$ \\
\hline Primary education & 232 & 41,7 \\
\hline Secondary education & 556 & 100,0 \\
\hline Total &
\end{tabular}

As Table 2 shows, the majority of the sample comes from primary education (58.3\%), while the rest from secondary education (41.7\%), The overwhelming majority of respondents are educators (75\%), followed by principals with $20.1 \%$ and finally $4.9 \%$ are vice principals.

\subsection{Results of the study}

The majority of teachers attended training programs related to their work during the previous two years (95.4\%), while only $4.63 \%$ did not. 
K. Kiriatzakou - Teachers' Educational Needs and Their Motives for Participation in Lifelong...

During the previous school year $13.6 \%$ did not attend any training program, $28.2 \%$ have attended at least one, $13.6 \%$ two programs, $13.4 \%$ participated in three, $10.5 \%$ attended four programs, $7.1 \%$ participated in five, $4.1 \%$ in six, $1.8 \%$ in seven, $1,1 \%$ in eight and the remaining percentage (6.6\%) participated in over eight training programs (Table 3).

Table 3. Frequency of attendance training programs during the last year

\begin{tabular}{c|c}
$\begin{array}{l}\text { Number of programs } \\
\text { during the lasts year }\end{array}$ & Percenta \\
\hline 0 & 13.6 \\
1 & 28.2 \\
2 & 13.6 \\
3 & 13.4 \\
4 & 10.5 \\
5 & 7.1 \\
6 & 4.1 \\
7 & 1.8 \\
8 & 1.1 \\
\hline More than programs & 6.6
\end{tabular}

Table 4. Percentage of teachers' participation at programs of specific duration

\begin{tabular}{|c|c|c|c|c|}
\hline & \multicolumn{4}{|c|}{ Duration of programs } \\
\hline $\begin{array}{l}\text { Number of } \\
\text { programs }\end{array}$ & $\mathbf{1 - 2 0}$ hours & $\mathbf{2 1 - 5 0}$ hours & $\begin{array}{c}\mathbf{5 1 - 1 0 0} \\
\text { hours }\end{array}$ & 101+ hours \\
\hline 0 & $\mathbf{2 7 . 1 \%}$ & $\mathbf{7 2 . 5 \%}$ & $\mathbf{8 5 . 4 \%}$ & $\mathbf{8 9 . 6 \%}$ \\
\hline 1 & $\mathbf{2 6 . 1 \%}$ & $\mathbf{2 2 \%}$ & $\mathbf{1 2 . 1 \%}$ & $9.5 \%$ \\
\hline 2 & $\mathbf{1 2 . 7 \%}$ & $3.4 \%$ & & \\
\hline 3 & $\mathbf{1 1 . 8 \%}$ & & & \\
\hline 4 & $6.8 \%$ & & & \\
\hline 5 & $7.5 \%$ & & & \\
\hline 6 & $1.1 \%$ & & & \\
\hline 10 & $4.3 \%$ & & & \\
\hline
\end{tabular}

According to the data of Table 4, 27.1\% did not attend a program of 20 hours, $26.1 \%$ have attended one of 1-20 hours, $12.7 \%$ participated in two programs, $11.8 \%$ have attended three, $6,8 \%$ four programs, $7.5 \%$ five and $1,1 \%$ have attended six, while $4,3 \%$ state that they have attended 10 programs of $1-20$ hours. $72.5 \%$ of the sample did not attend a program of 21-50 hours during the previous school year, 22\% have attended one program of 21-50 hours and $3.4 \%$ have attended two. A large percentage of teachers (85.4\%) did not attend a program of 51-10o hour in the previous school year, while only $12.1 \%$ have attended one and only $1.3 \%$ have attended two programs of $51-100$ hours. $89.6 \%$ of the sample did not take part in a training course of 101 hours or more, while only $9.5 \%$ participated in one program. training forms.

Table 5 shows the means and standard deviations of teachers' preferences about the 
Table 5. Means and standard deviations of sample preferences about the training forms

\begin{tabular}{|l|c|c|}
\hline Forms of training & Mean & SD \\
\hline Training in RTCs & $\mathbf{3 . 8 1}$ & 1.78 \\
\hline in-school training & $\mathbf{5 . 2 1}$ & 1.48 \\
\hline Distance learning & 4.97 & 1.76 \\
\hline Mixed training model & 5.11 & 1.63 \\
\hline $\begin{array}{l}\text { Participation in teacher education } \\
\text { networks/communities }\end{array}$ & 4.80 & 1.66 \\
\hline Mentoring & 4.96 & 1.64 \\
\hline $\begin{array}{l}\text { Teachers' exchanges through European } \\
\text { programs }\end{array}$ & 4.79 & 1.91 \\
\hline
\end{tabular}

\subsection{7-point Likert scale}

As can be seen, all the forms of training in Table 5 are scored by the majority of the sample with values from 5 to 7 , except those of the training in RTCs, exceeds the mean value 4 . With the exception of the factor training in RTCs, the average is around 4.97 in the rest of the cases.

Table 6. Percentage of teachers' participation in training programs of specific subjects

\begin{tabular}{|l|c|}
\hline Subjects of training programs & Percentages \\
\hline Stress management strategies & $7.50 \%$ \\
\hline Evaluation of the teaching process in classroom & $9.80 \%$ \\
\hline European dimension in education & $10.30 \%$ \\
\hline Evaluation/ grading of students & $10.70 \%$ \\
\hline Organization and administration of education & $10.90 \%$ \\
\hline Issues of Pedagogical psychology & $13.90 \%$ \\
\hline School unit evalution & $13.90 \%$ \\
\hline Special education & $15.70 \%$ \\
\hline Pedagogical methods of classroom management & $20.30 \%$ \\
\hline Interpersonal relationships in school units & $20.60 \%$ \\
\hline Promotion and support of innovation in education & $22.10 \%$ \\
\hline Dealing with learning disabilities & $27 \%$ \\
\hline Methodology of each subject & $27.60 \%$ \\
\hline Information and communication technology (ICT) & $31.10 \%$ \\
\hline New teaching methods & $32.90 \%$ \\
\hline
\end{tabular}

According to Table 6, higher participation rates are observed in new teaching methods (32.9\%) and New Technologies (31.1\%) followed by the themes of Teaching Methodology per subject (27.6\%) and Dealing with Learning Difficulties (27\%). Low participation rates are observed in training actions on stress management strategies (7.5\%) and topics related to the evaluation of the teaching process in the classroom (9.8\%) and students' evaluation/grading (10.7\%). Low participation rates include thematic issues related to the administration of education, such as the European dimension in education (10.3\%) and the organization and administration of education (10.9\%), which is partly due to the limited supply of training programs in these areas as well as the limited interest of teachers in the transition to the educational administration. 


\subsection{Teachers' educational needs}

Table 7 shows the means and standard deviations of the educational need factors as they developed from the Exploratory Factor Analysis (Bartlett's Sphericity Test: $x^{2}=5190,139$, $\mathrm{df}=120$ and $\mathrm{p}<0,001, \mathrm{KMO}=0,914, \mathrm{MSA}$ is in the range 0.887 to 0.937 , four factors with initial eigenvalues ranging from 1.032 to 7.456 and a total rate of variation interpreted by these factors of $70.43 \%)$.

Table 7. Means and standard deviations of the educational need factors

\begin{tabular}{|c|l|c|c|c|}
\hline & \multicolumn{1}{|c|}{ Factors } & N & Mean & SD \\
\hline 1 & Pedagogical and psychological issues & 556 & 5.10 & 1.31 \\
\hline 2 & Educational work in the classroom & 556 & 5.64 & 1.18 \\
\hline 3 & Classroom rating & 556 & 4.93 & 1.50 \\
\hline 4 & Administration of education & 556 & 4.33 & 1.68 \\
\hline
\end{tabular}

As Table 7 shows, the average of all factors exceeds the average value 4. As expected, the mean of the need to attend training programs on educational administration approaches a mere 4.33. This means that teachers do not share the need for participation in managementrelated programs to the same extent as other themes.

\subsection{Motives of participation in training}

Table 8 shows the means and standard deviations of the motives' factors of participation in training as they developed after the Confirmatory Factor Analysis $\left(\chi^{2} / \mathrm{df}=4,68\right.$, $\mathrm{NFI}=0.919, \mathrm{CFI}=0.935 \mathrm{RMSEA}=0.82, \mathrm{SRMR}=0.523$ ).

As can be seen from the data in Table 8, the means of the career development and personal pleasure factors- as reasons for participation- are lower than the average 4, in contrast with the mean of the professional and personal development factor, which is very high.

Table 8. Means and standard deviation of the motives' factors

\begin{tabular}{|l|l|c|c|c|}
\hline & Factors & N & Mean & SD \\
\hline $\mathbf{1}$ & Professional and personal development & 556 & 6.14 & 0.92 \\
\hline $\mathbf{2}$ & Career development & 556 & 3.4 & 1.48 \\
\hline 3 & Personal pleasure & 556 & 3.12 & 1.30 \\
\hline
\end{tabular}

\section{Further statistical analysis}

Non-parametric tests were carried out to establish the relationship between the demographic characteristics of sex and sector service of teachers (primary or secondary education) with their perceptions of their educational needs. Mann-Whitney $U$ tests were then carried out to determine the degree of desire to attend training programs on specific topics. The results of the test in Table 9 showed that the degree of need to attend training programs in pedagogy and psychology for female teachers is statistically higher than that of male teachers ( $U=25659$, $\mathrm{N} 1=160, \mathrm{~N} 2=396, \mathrm{p}=0.001$, bilateral control). Similarly, the degree of desire to attend programs related to the teaching work was found to be statistically higher in women than in men ( $\mathrm{U}=\mathbf{2 6 2 4 4}$, $\mathrm{N} 1=160, \mathrm{~N} 2=396, \mathrm{p}=0.001$, bi-lateral control). The same result occurred with the need to attend training programs concerning the evaluation in the classroom $(\mathrm{U}=27096, \mathrm{~N} 1=160, \mathrm{~N} 2=396$, $\mathrm{p}=0.007$, bi-lateral control). As for the degree of desire for programs about the administration of education, the perceptions of men are statistically higher than those of their women colleagues (U=27363, N1=160, N2=396, $\mathrm{p}=0.011$, bi-directional control). 
Table 9. Mann-Whitney U test for independent samples of teachers' training needs based on gender

\begin{tabular}{|c|c|c|c|c|c|c|}
\hline $\begin{array}{l}\text { Factors of degree of } \\
\text { desire to follow } \\
\text { training programs } \\
\text { about: }\end{array}$ & Gender & $\mathbf{N}$ & $\begin{array}{l}\text { Mean } \\
\text { Rank }\end{array}$ & $\begin{array}{c}\text { Mann- } \\
\text { Whitney } \\
\text { U test }\end{array}$ & $\mathbf{Z}$ & $\mathbf{p}$ \\
\hline \multirow[t]{2}{*}{\begin{tabular}{|l} 
Pedagogical and \\
psychological issues
\end{tabular}} & Men & $\begin{array}{l}160 \\
160 \\
\end{array}$ & $\begin{array}{l}240.87 \\
312.64\end{array}$ & \multirow[t]{2}{*}{25659.0} & \multirow[t]{2}{*}{-3.516} & \multirow[t]{2}{*}{0.001} \\
\hline & Women & 396 & 293.73 & & & \\
\hline \multirow{2}{*}{$\begin{array}{l}\text { Teaching work in the } \\
\text { classroom }\end{array}$} & Men & 160 & 244.53 & \multirow{2}{*}{26244.0} & \multirow{2}{*}{-3.179} & \multirow{2}{*}{0.001} \\
\hline & Women & 396 & 292.23 & & & \\
\hline \multirow[t]{2}{*}{ Classroom rating } & Men & 160 & 249.85 & \multirow{2}{*}{27096.0} & \multirow{2}{*}{-2.697} & \multirow{2}{*}{0.007} \\
\hline & Women & 396 & 290.08 & & & \\
\hline \multirow{2}{*}{$\begin{array}{l}\text { Administration of } \\
\text { education }\end{array}$} & Men & 160 & 305.48 & \multirow{2}{*}{27363.0} & \multirow{2}{*}{-2.527} & \multirow{2}{*}{0.011} \\
\hline & Women & 396 & 267.60 & & & \\
\hline
\end{tabular}

Mann-Whitney's U test was then conducted to investigate the degree of desire to attend training programs with specific topics relative to the sector of service that research participants serve in. The test revealed that the degree of desire for monitoring programs in pedagogy and in psychology is statistically higher in primary school teachers than in secondary school teachers $(\mathrm{U}=26522, \mathrm{~N} 1=324, \mathrm{~N} 2=232, \mathrm{p}=0.001$, bi-lateral control). Also, the degree of willingness to attend programs about the educational management is statistically higher among teachers of primary education than teachers of secondary education $(\mathrm{U}=33376.5, \mathrm{~N} 1=324$, $\mathrm{N} 2=232, \mathrm{p}=0.024$, bi-directional control).

To facilitate the statistical analysis of the data a grouping of the sample subjects was made in relation to age and three age groups were created. The first group is for teachers aged up to 40 years old $(\mathrm{N}=128)$, second teachers from 41 to 50 years old $(\mathrm{N}=264)$ and the third group includes teachers from 51 years of age $(\mathrm{N}=164)$. A Kruskal-Wallis test was carried out to look into the relationship between the degree of desire to attend programs with specific themes and age. It was found that the degree of desire for programs concerning the administration of education differs significantly $\left(\mathrm{x}^{2}=6.483, \mathrm{df}=2, \mathrm{n}^{2}=0.030, \mathrm{p}=0.001\right)$. Then a Mann-Whitney U test (Table 10) was conducted to find out which pairs of age groups present a statistically significant difference in the degree of desire to attend programs in the management of education. It was found that the degree of desire is statistically higher for teachers of 51+ years of age than for teachers up to 40 years old ( $\mathrm{U}=7756.5, \mathrm{~N} 1=128, \mathrm{~N} 2=164, \mathrm{p}=0.001$, bilateral control) or teachers from 41 to 50 years old (U=17666.5, N1=264, N2=164, p=0.001, bilateral control).

Table 10. Mann-Whitney U test for independent samples of teachers' training needs of teachers based on age

\begin{tabular}{|c|c|c|c|c|c|c|}
\hline \begin{tabular}{|l|} 
Factor of degree \\
of desire to follow \\
training \\
programs about:
\end{tabular} & Age group & $\mathbf{N}$ & $\begin{array}{l}\text { Mean } \\
\text { Rank }\end{array}$ & $\begin{array}{c}\text { Mann- } \\
\text { Whitney } \\
\text { U test }\end{array}$ & $\mathbf{Z}$ & $\mathbf{P}$ \\
\hline \multirow{4}{*}{$\begin{array}{l}\text { Administration of } \\
\text { education }\end{array}$} & Up to 40 years & 128 & 125,10 & \multirow{2}{*}{7756.5} & \multirow{2}{*}{-3.843} & \multirow{2}{*}{0.001} \\
\hline & 51 and up & 164 & 163,20 & & & \\
\hline & 41-5o years old & 264 & 199,42 & \multirow{2}{*}{17666.5} & \multirow{2}{*}{-3.213} & \multirow{2}{*}{0.001} \\
\hline & 51 and up & 164 & 238,78 & & & \\
\hline
\end{tabular}

Regarding the motives for participating in training programs, a Mann-Whitney's U test found that women's rates in attending training programs for professional and personal growth were statistically higher than these of men $(\mathrm{U}=22794, \mathrm{~N} 1=160, \mathrm{~N} 2=396, \mathrm{p}=0.001$, bi-lateral 
control). Regarding the sector of service, the Mann-Whitney $U$ test found that the values of the factor of personal pleasure are higher in the primary school educators than those of Secondary Education teachers ( $\mathrm{U}=32763.5, \mathrm{~N} 1=324, \mathrm{~N} 2=262, \mathrm{p}=0.010$, bi-directional control).

The Kruskal-Wallis test for the relationship of participation ratios with age showed that only the factor of career development among the three age groups differs significantly $\left(\mathrm{x}^{2}=12.813, \mathrm{df}=2, \mathrm{p}=0.002, \mathrm{n} 2=0.024\right.$, bilateral control). The Mann-Whitney U test (Table 11), showed that the values of the career development factor in teachers up to 40 years of age are statistically higher than those of teachers from 41 to 50 years of age $(U=14158,5, N 1=128, N 2=264$, $\mathrm{p}=0.009$, bi-directional control), and that the specific factor values for teachers aged up to 41 years are statistically higher than those for teachers aged 51 and above (U=8014.5, N1=128, N2=164, $\mathrm{p}=0.001$, bilateral control) whereas values among age groups of 41-50 years and 51 years of age and above were not statistically significant.

Table 11. Mann-Whitney U test for independent samples of the motives of participation by age

\begin{tabular}{|c|c|c|c|c|c|c|}
\hline \begin{tabular}{|l} 
Factor for \\
participation in \\
training
\end{tabular} & Age group & $\mathbf{N}$ & $\begin{array}{l}\text { Mean } \\
\text { Rank }\end{array}$ & $\begin{array}{c}\text { Mann- } \\
\text { Whitney } \\
\text { U test }\end{array}$ & $\mathbf{Z}$ & $\mathbf{p}$ \\
\hline \multirow{6}{*}{$\begin{array}{l}\text { Professional } \\
\text { evolution }\end{array}$} & Up to 40 years old & 128 & 217.89 & \multirow{2}{*}{14158.5} & \multirow{2}{*}{-2.608} & \multirow{2}{*}{0.009} \\
\hline & 41-50 years old & 264 & 192.39 & & & \\
\hline & Up to 40 years old & 128 & 165.89 & \multirow{2}{*}{8014.5} & \multirow{2}{*}{-3.474} & \multirow{2}{*}{0.001} \\
\hline & 51 and up & 164 & 131.37 & & & \\
\hline & $41-50$ years old & 264 & 221.43 & \multirow{2}{*}{19817.5} & \multirow{2}{*}{-1.475} & \multirow{2}{*}{0.140} \\
\hline & 51and up & 164 & 203.34 & & & \\
\hline
\end{tabular}

\section{Discussion}

According to the data of this study the majority of the sample reply that they have been trained through the last two years. However, the majority of the sample prefers training forms such as in-school training, distance learning, and mix training model to training in Regional Training Centers due to the fact that these centers provide "traditional" model programs. Regarding teacher training, a survey conducted on a sample of 305 secondary school teachers found that the overwhelming majority of the sample had attended a training course besides that of introductory training (National Center for Social Research \& KEDROS SA 2008). Regarding the participation in specific programs, higher participation rates are observed in programs related to the teaching work and the professional development of the teachers and low participation rates include thematic issues related to the administration of education.

The educational needs of the sample focus on topics such as Educational work in the classroom ( $M=5.64)$, Pedagogical and psychological issues $(M=5.1)$, evaluation of the classroom $(M=4.93)$ and to a lesser extent on topics related to the administration of education $(M=4.33)$. At the survey of the National Center for Social Research (2010), they found that the educational needs of the teachers are mainly related to their daily pedagogical practice. In the question of educational needs the first choice of teachers was "pedagogical psychology", followed by "learning and teaching theories". Papanaoum (2003), in her research, asked teachers to characterize the importance they attach to specific subjects of training based on their own current needs. The results showed that a high percentage seek training in topics such as: psychology, teaching methodology, general education issues, special education, assessment of students and the administrative and pedagogical dimension of their role. Goliaris' (1998) research concerned the educational needs of primary school teachers and was carried out in the context of the $2^{\text {nd }}$ Regional Training Center in 1996 in order to improve the training programs offered by this center. The results of the research 
have shown that theoretical areas which teachers wish to address are, in order of priority: (a) child's psychology, (b) pedagogy, (c) Special education, (d) Health Education, (e) Research methodology, (f) History and Greek Culture, (g) Administration of Education, (h) Education of Technology, (i) Educational evaluation, (j) Sociology, and (k) European Dimension of Education, areas related to their teaching work.

In 2007, in a survey of the Pedagogical Institute with a sample of 4,164 teachers from 100 school units, the vast majority ( $83 \%$ of the total) wanted discussion of problems faced by teachers about the daily educational act to be included in the training programs (Pedagogical Institute, 2008: 43). In addition, the thematic area considered by most sample educators (77\% of the total) as more important in the field of education is the management of school reality (students' behavioral problems, conflict management, diversity of student population, etc.) (Ibid., 46). In a more recent study of the educational needs survey conducted by the Pedagogical Institute in 2010, in the framework of the Major Teacher Training Program, a sample of 27,785 teachers of all specialties and levels of education (Pedagogical Institute, 2010), three out of the top five teacher preferences refer to teaching work ("modern teaching approaches", "exploitation of new technologies" and "didactic methodology on cognitive subjects") both in relation to the classroom ("school classroom management" and "developing creative relationships with students and parents”) (Ibid., 55).

Regarding the motives of participation to training courses, teachers participate for their professional and personal development $(M=6.13)$ and to a lesser extent for their personal pleasure or their career development. Based on the world literature, the main incentives for adult participation in training programs are grouped into the following categories: (a) development of social relations, (b) external expectations, (c) social contribution, (d) professional upgrading, (e) and (f) interest in knowledge (Boshier, 1971; Boshier, 1973; Boshier \& Collins, 1985). At the Greek level, the recent study by Karalis (2013) in education programs, the answer "because I like to learn new things" gathered the highest rates, while high rates are accounted for the answer "because education has to last throughout our lives". High acceptance rates are also noted for reasons of professional development such as an increase in earnings, formal qualifications, finding better work, and securing a job. A survey at 223 Primary Education Teachers in the Eastern Macedonia and Thrace Region found that the two main factors influencing their participation in training were firstly the personal need for development and, secondly, the acquisition of better qualifications (Salpigidis, 2011). At the survey of the National Center for Social Research (2008) the most important reasons teachers would follow a training program in the future is the improvement of teaching methods (46\%) and techniques (25\%), followed by improvement of their scientific knowledge. Formal certification from a training program does not seem to be a particularly important motivator (0.7\%). Moreover, there is no real motivation to get rid of the daily routine (4.7\%) and to meet with colleagues (4.4\%).

The study also revealed that women are more willing to take part in educational programs on pedagogical and psychological issues, with topics related to classroom teaching and classroom evaluation than men. However, men declare themselves more receptive to taking part in training programs for the administration of education. This may be attributed to the fact that the percentage of women claiming a managerial position in the Greek educational system is relatively lower than that of men, although women teachers are outnumber male teachers. In addition, primary school teachers are more willing to attend programs on pedagogical and psychological issues and on the administration of education than secondary school teachers.

Regarding the reasons of participation in training, women seem to be more involved for their personal and professional development than male teachers. Primary school teachers also report to be involved in training for personal pleasure to a greater extent than secondary school teachers. Teachers aged up to 40 years consider that they participate in training programs for career development to a greater extent than the other age groups. 


\section{Proposals}

According to the literature and the results of this study, teacher training should be decentralized and respond to identified training needs of teachers, to be provided by various bodies, to take many forms and to be able to integrate a variety of training activities. It must be short, repetitive but long-range in terms of the number of teachers targeted. It has to be closely related with educational research and school practice, to use work types tailored to adult learning experiences.

According to the above, certain aspects of a framework for improving the quality of education are the planning of teachers' training through the evaluation of training programs, the exploitation of the results of good practices, the recording of teachers' perceptions of their profession, the organizational development of training, the delimitation of procedures/criteria/methodology of design, organization, implementation and evaluation of programs. There is also need for systematic information on the planning and implementation of training activities and dissemination of training actions and related materials.

\section{Acknowledgements}

This research did not receive any specific grant from funding agencies in the public commercial, or not-for-profit sectors.

The author declares no competing interests.

\section{References}

Borraz, O. (2007). Governing standards: The rise of standardization processes in France and in the EU. In: Governance: An International Journal of Policy, Administration, and Institutions, 2O(1), 5784.

Boshier, R., \& Collins, J. (1973). The Houle typology after twenty-two years: A large-scale empirical test. Adult Education Quarterly, 35(3), 113-130.

Boshier, R. (1971). Motivational orientations of adult education participants: A factor analytic exploration of Houle's typology. Adult Education Quarterly, 21 (2): 3-26.

Boshier, R. (1973). Educational participation and dropout: A theoretical model. Adult Education Quarterly, 23(4), 255-282.

Buchberger, F., Campos, B. P., Kallos, D., \& Stephenson, J. (Eds.) (2000). Green paper on teacher education in Europe. Thematic Network on Teacher Education, Umea University, Sweden.

Day, C. (2003). The evolution of teachers, translated by Anthi Vakakis. Tepotheto: D Dardanos.

Eurydice (2004). Key topics in education in Europe. Volume 3: The teaching profession in Europe: Profile, trends and concerns. Report IV: Keeping teaching attractive for the 21 st century - General Lower Secondary Education. Brussels: Eurydice European Unit.

Hargreaves, A., \& Fullan, M. (1995). The evolution of teachers, translated by Panagiota Chatzipantelli. Athens: Pataki.

Harvey, L., \& Green, D. (1993). Defining quality. Assessment and Evaluation in Higher Education, 18(1), 934 .

Harvey, L., \& Stensaker, B. (2008). Quality culture: Understandings, boundaries and linkages. European Journal of Education, 43(4), 427-442. 
Open Journal for Educational Research, 2018, 2(2), 103-116.

Karalis, Th. (2013). Incentives and obstacles for the participation of adults in lifelong learning, Athens: GSEE Labor Institute

Keiny, S. (1994). Constructivism and teachers' professional development. Teaching and Teacher Education, $10(2), 157-167$.

Knight, P., \& Trowler, P. (2000). Editorial. Quality in Higher Education, 6(2), 109-114.

Morley, L., \& Rassool, N. (200o). School effectiveness and the displacement of equity discourses in education. Race Ethnicity and Education, 3(3), 237-258.

National Center for Social Research \& KEDROS SA (2008). Study: Detection of training needs in secondary education. Athens: National Center for Social Research \& KEDROS SA. Available at: http://reader.ekt.gr/bookReader/show/index.php?lib=EDULLL\&item=1158\&bitstream=115 8 01\#page/106/mode/2up

OECD (2005). Teachers matter: Attracting, developing and retaining effective teachers. Paris: OECD.

Papanaoum, Z. (2014). Supporting teachers' professional development: principles and practices of training. In: Z. Papanaum \& M. Liakopoulou (Eds.), Supporting the professional development of teachers. Training Manual (pp. 13-20). Action "Training of teachers and members of the educational community".

Papanaoum, Z. (2003). The profession of teacher: Theoretical and empirical approach. Typothito: Athens.

Pasias, G., \& Roussakis, Y. (2009). Towards the European Panopticon: EU discourses and policies in education and training 1992-2007. In: R. Cowen \& A. M. Kazamias (Eds.), International handbook of comparative education (pp. 479-495). Dordrecht: Springer Publishers.

Pedagogical Institute (2010). The contribution of investigating training needs to training teacher: Comparative Interpretation of Results. Athens: Pedagogical Institute.

Salpigidis, Andreas (2011). The educational needs of the teachers in Primary Education: An empirical exploration of the Western Macedonia and Thrace schools, based on teachers' perceptions. Thessaloniki: University of Macedonia, Department of Educational Sciences and Social Policy, Postgraduate essay.

Sipitanou, A. (2005). Institutions and policies of the European Union for lifelong learning: A criticalinterpretive approach. Thessaloniki: University of Macedonia Publishing.

Ursin, J. (2007). In quality we trust? The case for quality assurance in Finnish universities. In: D. Epstein et al. (Eds.), Geographies of knowledge, geometrics of power: Higher education in the $21^{\text {st }}$ century, World year book of education 2007. London: Routledge Falmer.

Van Damme, D. (2003). Standards and Indicators in Institutional and Programme Accreditation in Higher Education. Paper for UNESCO-CEPES.

Vidovich, L. (2001). That Chameleon "Quality": The multiple and contradictory discourses of "quality" policy in Australian higher education. Discourse: Studies in the Cultural Politics of Education, 22(2), 249-261.

Xohellis, P. (2005). The teacher in the modern world. Athens: Typothiito G. Dardanos. 
K. Kiriatzakou - Teachers' Educational Needs and Their Motives for Participation in Lifelong...

C O A $\mathbf{s}$ 